\title{
OPTIMASI AKTIVITAS ANTIOKSIDAN PEPTIDA AKTIF DARI CEKER AYAM MELALUI HIDROLISIS ENZIM PAPAIN
}

\author{
Optimization of Active Peptides Antioxidant Activity from Chicken Feet with Papain \\ Enzyme Hydrolysis
}

\author{
Edy Susanto $^{1)}$, Djalal Rosyidi ${ }^{2)}$, Lilik Eka Radiati ${ }^{2)}$ \\ 1) Program Studi Peternakan, Universitas Islam Lamongan, Jl. Veteran 53A Lamongan,Jawa Timur, Indonesia \\ ${ }^{2)}$ Fakultas Peternakan, Universitas Brawijaya, Jl. Veteran Malang, Jawa Timur, Indonesia.65145 \\ Email : ahzasusanto@gmail.com
}

Diterima 8 Februari 2018; diterima pasca revisi 20 Maret 2018

Layak diterbitkan 28 Maret 2018

\begin{abstract}
The objective of this study was to optimization antioxidant activity of active peptides of chicken feet with papain hydrolysis. The research method was experimental design conducted using Factorial Completely Randomized Design. Treatments included papain concentration (control (0\%) , 1\%, 2\% and 4\%) and Incubation time (24 hours, 36 hours and 48 hours) were repeated four times. The variables observed were proximate analysis,microstructure, dissolved protein concentration and antioxidant activity. The results indicate that the treatment of papain concentration and incubation time variations in chicken feet protein extraction gave a differenceinfluence $(P<0.05)$ to the concentration of solubility protein and antioxidant activity. The interaction of 3\% papain concentration and 36 hours incubation time resulted in the highest antioxidant activity amount 55.10 $\pm 2.24 \%$. It could be concluded that chicken feet produced bioctive peptide compound that gave high antioxidant activity optimized by hydrolysis of papain enzymes thereby increasing their functional value.
\end{abstract}

Keywords : Chicken feet; antioxidant activity; papain enzyme

\begin{abstract}
ABSTRAK
Penelitian ini bertujuan untuk mengoptimasi aktivitas antioksidan peptida aktif yang bersumber dari ceker ayam melalui hidrolisis enzim papain. Metode penelitian adalah eksperimental dengan Rancangan Acak Lengkap Faktorial. Perlakuan meliputi faktor konsentrasi enzim papain (kontrol (0\%), 1\%, 2\% dan 3\%) dan faktor lama pemeraman (24 jam, 36 jam dan 48 jam) masing-masing diulang 4 kali. Variabel yang diamati meliputi analisis proksimat, mikrostruktur, konsentrasi protein terlarut dan aktivitas antioksidan. Hasil penelitian ini menunjukkan perlakuan variasi konsentrasi enzim papain dan lama pemeraman memberikan perbedaan pengaruh yang nyata $(P<0,05)$ terhadap konsentrasi protein terlarut dan aktivitas antioksidan. Interaksi konsentrasi $3 \%$ enzim papain dan lama pemeraman 36 jam menghasilkan aktivitas antioksidan tertinggi sebesar 55,10 $\pm 2,24 \%$. Kesimpulan pada penelitian ini adalah ceker ayam menghasilkan komponen peptida bioaktif yang menghasilkan aktivitas antioksidan yang tinggi yang dioptimalkan melalui hidrolisis enzim papain sehingga meningkatkan nilai fungsionalnya.
\end{abstract}

Kata kunci : Ceker Aya; aktivitas antioksida; enzim papain 


\section{PENDAHULUAN}

mailto:ahzasusanto@gmail.comIndustrialisasi telah menyebabkan polusi dan cemaran lingkungan.Hal ini menyebabkan paparan radikal bebas yang sangat tinggi. Sumber antioksidan banyak ditemukan dari bahan alami, namun masih sedikit jumlah sumber antioksidan yang bermanfaat sekaligus sebagai sumber nutrisi asam amino. Escudero et al. (2013) menyatakan bahwa peptida antioksidan dapat mengikat logam dan aktivitas donor ion hidrogen atau elektron untuk menghentikan rantai reaksi radikal bebas tersebut dalam tubuh. Produksi ceker ayam di Indonesia dapat dihitung dengan asumsi produksi daging. Apabila produksi daging ayam ras sebesar 1.400,47 ribu ton dikalikan konversi karkas 1,33 $\mathrm{kg}$ per ekor ayam maka dapat diperkirakan terdapat 1.867.293.333 pasang potongan ceker ayam per tahun. Sebagian besar hanya dimanfaatkan sebagai variasi olahan pangan oleh masyarakat Indonesia, seperti soto ceker, mie ceker, bakso ceker dan sebagainya. Hal ini menjadi dasar perlunya peningkatan nilai ekonomis dan nilai fungsionalnya.

Ceker adalah bagian kaki ayam sebagai hasil samping yang mempunyai nilai fungsional dan ekonomis rendah. Liu et al. (2012) menyatakan bahwa lebih dari $40 \%$ protein ceker ayam tersusun dari protein sukar larut dan mempunyai tingkat kecernaan yang rendah saat dikonsumsi manusia. Protein ceker ayam dapat dieksplorasi menghasilkan mikronutrien yang fungsional. Protein tersebut berpotensi menghasilkan asam amino hidrofobik yang mampu mendonorkan ion hidrogen dalam mereduksi radikal bebas seperti DPPH (Lin et al., 2010).

Proses hidrolisis diharapkan dapat memberikan peptida antioksidan alami dan mengerahkan sifat antioksidan yang lebih tinggi. Hidrolisis enzimatis dapat dipilih karena

*Corresponding author:

Edy Susanto

Email : ahzasusanto@gmail.com

Program Studi Peternakan, Universitas Islam Lamongan, Jl. Veteran 53A Lamongan, Jawa Timur, Indonesia lebih efektif pada target protein yang di pecah dan aman untuk pemanfaatan produknya pada bidang pangan, kosmetik maupun farmasi.

Enzim papain merupakan golongan enzim eksopeptidase yang sering digunakan karena bisa menghindari kerusakan substrat serta pengadaannya sangat mudah dan relatif murah. Hidrolisis enzimatis merupakan penggunaan enzim dalam menghidrolisis protein menghasilkan produk hidrolisat yang terhindar dari perubahan dan kerusakan produk. Beberapa enzim dapat digunakan dalam memutus rantai polipeptida protein diantaranya enzim papain. Enzim ini tersedia banyak dan lebih mudah di dapat di pasaran. Beberapa penelitian juga menyebutkan enzim papain lebih unggul dalam menghasilkan peptida yang bersifat antioksidan. Sehingga perlu dilakukan optimasi aktivitas antioksidan peptida aktif dari ceker ayam melalui hidrolisis enzim papain.

Penelitian tentang peptida aktif antioksidan telah banyak dilakukan pada beberapa jenis daging. Namun belum pernah diteliti tentang aktivitas antioksidan yang berhubungan dengan protein terlarut pada ceker ayam serta penggunaan enzim papain terhadap peptida aktif yang diperoleh. Tujuan penelitian ini adalah mengoptimasi aktivitas antioksidan peptida aktif yang bersumber dari ceker ayam melalui penggunaan konsentrasi enzim papain dan lama pemeraman yang berbeda

\section{METODE PENELITIAN}

\section{Lokasi Penelitian}

Preparasi sampel bubuk ceker ayam dilakukan di Laboratorium Dasar Fakultas Peternakan Universitas Islam Lamongan. Hidrolisis enzimatis dilakukan di Laboratorium Teknologi Hasil Ternak Fakultas Peternakan Universitas Brawijaya. Ekstraksi peptida aktif dilakukan di Laboratorium Epidemiologi Fakultas Peternakan Universitas Brawijaya.

How to cite:

Susanto, E., Rosyidi, D., \& Radiati, L.E. (2018). Optimasi Aktivitas Antioksidan Peptida Aktif dari Ceker Ayam Melalui Hidrolisis Enzim Papain. Jurnal Ilmu dan Teknologi Hasil Ternak, 13 (1), 14-26 
Pengujian proksimat dilakukan di Laboratorium Pengujian Mutu dan Keamanan Pangan Fakultas Teknologi Pertanian Universitas Brawijaya. Pengujian protein terlarut dan aktivitas antioksidan dilakukan di Laboratorium Farmakologi Universitas Airlangga dan pengujian SEM dilakukan di Institut BioSains Universitas Brawijaya.

\section{Bahan}

Ceker ayam diperoleh dari ayam broiler jenis strain Lohman 202 produksi PT.Panca Patriot yang berasal dari peternakan UPT Agri Science Technopark Universitas Islam Lamongan. $\left(\mathrm{NH}_{4}\right)_{2} \mathrm{CO}_{3}$ (Merck), Ethanol $40 \%$ (Merck), petrolium ether (Merck), $\mathrm{NaSO} 4$ anhidrat (Merck), CuSO4 (Merck), H2SO4 (Merck), Zn (Merck), $\mathrm{NaOH} \mathrm{40 \%} \mathrm{(Merck),}$ HCL 0,1 N (Merck), indikator metyl red 15 (Merck), $\mathrm{NaOH} \quad 0,1 \quad \mathrm{~N}$ (Merck), Buffer phosphate $(0,2 \mathrm{mmol} / \mathrm{L}, \mathrm{pH}$ 7,2) (Merck), akuades (Merck), reagen Bradford (Sigma), Bovine Serum Albumine (BSA) (Sigma),Asam asetat glasial (Merck), dan larutan DPPH 0,1 mM (Sigma). Papain Dry Extract (Sigma).

\section{Alat}

Analitical balance (Mettler PM 200 Switzerland), Vortex (Janke 43480), refrigerated (Panasonic), magnetic stirrer 3,5 $\mathrm{cm}$ (Labinco), centrifuge Refrigerated Mikro $22 \mathrm{R}$ (Hettich), dan pH meter CG.818T (Schoot Gerate), Water bath digital tipe J.26, Shaker (Hettich), Blender (Panasonic), Oven (Hettich), eppendorf, micropippet $10 \mu 1-1000 \mu \mathrm{l}$ (Hamilton syringe), beaker glass (Pyrex), blue tip, yellow tip, micropippet $10 \mu \mathrm{l}-1000 \mu \mathrm{l}$ (Hamilton syringe), kuvet, spektrofotometer UV-2100 (Unico), soxlet unit, Kjeldhal unit, seperangkat alat Scanning Electron Microscopic (SEM) tipe JSM-6360LA.

\section{Metode Preparasi Sampel Bubuk Ceker Ayam}

Preparasi dikerjakan berdasarkan metode Susanto et al. (2018) dan Widyaningsih dkk. (2015) yaitu: Pengambilan sampel ceker ayam yang seragam dari jenis ayam strain Lohman
202, kisaran umur 34-36 hari dan bobot badan 1,8-1,9 kg, dilayukan (aging) selama 8 jam pada suhu $16^{\circ} \mathrm{C}$. Sortasi dan pengulitan dengan cara pembersihan ceker ayam dari kuku, kulit terluarnya dan kotoran-kotoran yang menempel pada bagian ceker dengan tujuan mendapatkan bahan baku yang bersih dan baik.

Selanjutnya dilakukan pressure cooker selama 5 menit. Selanjutnya dilakukan penggilingan basah menggunakan blender kering, sampel ceker ayam yang digiling dalam kondisi setengah basah. Pengeringan dilakukan dalam oven pada suhu $40^{\circ} \mathrm{C}$ selama 24 jam dan penggilingan kering dengan blender kering dan disaring agar diperoleh bubuk ceker yang seragam (60 mes) dan bertekstur halus.

\section{Metode Hidrolisis dan Ekstraksi Peptida Aktif}

Ekstraksi peptida aktif ceker ayam menggunakan kombinasi metode Susanto et al. (2018), Xing et al. (2016) danWidyaningsih dkk. (2015) yang dimodifikasi, yaitu : Sampel bubuk ceker ayam diambil sebanyak 20 gram, ditambahkan $80 \mathrm{ml}$ buffer phosphate $(0,2$ $\mathrm{mmol} / \mathrm{L}$, $\mathrm{pH} 7,2)$, di homogenasi / vortex dengan kecepatan 6.000 rpm selama 10 detik sebanyak 3 kali ((Xing et al., 2016)). Proses hidrolisis dilakukan dengan penambahan enzim papain dengan konsentrasi $0 \%, 1 \%, 2 \%$ dan 3\% dengan lama pemeraman 24 jam, 36 jam dan 48 jam. Ditambahkan asam asetat $\left(\mathrm{CH}_{3} \mathrm{COOH}\right)$ hingga mencapai pH 4 ((Susanto et al., 2018)). Dilakukan pemanasan $50^{\circ} \mathrm{C}$ selama 10 menit dengan hot magnetic stirer ((Susanto et al., 2018)).

Selanjutnya dimaserasi menggunakan shaker dengan kecepatan $100 \mathrm{rpm}$ selama 24 jam (Widyaningsih dkk., 2015). Pelarutan dilakukan menggunakan pelarut ammonium bikarbonat $2 \mathrm{M} \quad\left(\mathrm{NH}_{4}\right)_{2} \mathrm{CO}_{3} \quad(1: 4)$ dengan menggunakan metode maserasi (Widyaningsih dkk., 2015). Selanjutnya dilakukan sentrifugasi pada $5000 \mathrm{x}$ g pada suhu $4^{\circ} \mathrm{C}$ selama 15 menit. Supernatan hasil ekstraksi dikeringkan dengan menggunakan freeze dryer(Widyaningsih dkk., 2015). 
Pengeringan menggunakan freeze dryer bertujuan untuk menghilangkan pelarut yang masih menempel pada supernatan dan agar hasil ekstrak yang diperoleh dalam bentuk bubuk dapat disimpan untuk keperluan analisis yang lebih lama.

\section{Metode Analisa Proksimat}

Analisis proksimat terhadap sampel hasil preparasi ceker ayam, meliputi: kadar air diukur berdasarkan metode

AOAC (2005:950.46),kadar lemak diukur berdasarkan metode AOAC (2005:960.39) ,kadar protein total diukur berdasarkan metode AOAC (2005:992.15), kadar abu diukur berdasarkan metode AOAC (2005:992.19), karbohidrat diukur berdasarkan metode AOAC (2005:992.8)

\section{Metode Penentuan Konsentrasi Protein Terlarut}

Dilakukan dengan Metode Bradford( 1976) karena paling cepat dan banyak digunakan. Dikutip (Rahmawati dkk., 2013) bahwa metode Bradford digunakan untuk mengukur konsentrasi protein totalsecara kolorimetri dalam larutan. dengan pewarna Coomassie Brillant Blue (CBB) sebagai indikator. $\mathrm{CBB}$ berikatan dengan protein dalamlarutan yang bersifat asam sehingga memberikan warna biru, karena pewarna tersebutdiprotonasi oleh gugus amino dari lisin dan triptophan selanjutnya mengikat padadaerah hidrofobik protein sehingga mengubah warnanya menjadi biru. Perubahan warna tersebut menjadi dasar larutan dapat diukur absorbansinya menggunakanspektrofotometer visibel pada panjang gelombang 465-595 nm dengan menggunakan larutan standar Bovine Serum Albumine (BSA).

\section{Metode Penentuan Mikrostruktur}

Penentuan Mikrostruktur dengan menggunakan SEM(Scanning Electron Microscopy) (Damez and Clerjon, 2008)yaitu sampel cair protein terlarut diambil dengan pipet pasteur dan diteteskan pada gelas objek 16 $\mathrm{mm}^{2}$. Selanjutnya dikeringbekukan dengan metode Critical Point Drying (CPD). Sampel ditempelkan pada set holder dengan perekat ganda, kemudian dilapisi dengan logam emas dalam keadaan vakum. Setelah itu, sampel dimasukkan pada tempatnya di dalam SEM, kemudian Gambar topografi diamati dan dilakukan perbesaran > 5000 kali.

\section{Metode Penentuan Aktivitas Antioksidan}

Analisis aktivitas ntioksidan dilakukan dengan metode DPPH ((Molyneux, 2004)) yaitu sampel diambil sebanyak $0,5 \mathrm{~mL}$, Ditambahkan 20 ppm DPPH (2,2-Diphenyl-1-picrylhydrazyl) kemudian dikocok, diinkubasi dalam kondisi gelap selama 30 menit, Diukur absorbansinya pada panjang gelombang $517 \mathrm{~nm}$, DPPH sebagai kontrol negatif diukur absorbansinya pada panjang gelombang $517 \mathrm{~nm}$, dihitung \% Aktivitas antioksidan dengan persamaan

$\%$ A.A $=$ Abs. DPPH - Abs. Sampelx $100 \%$ Abs. DPPH

\section{Analisis Data}

Data hasil peneltian akan dianalisis dengan ANOVA, jika terdapat perbedaan pengaruh akan dilanjutkan dengan uji duncan dengan menggunakan aplikasi perangkat lunak SPSS versi 16.0 (Subali, 2010)).

\section{HASIL DAN PEMBAHASAN}

\section{Komposisi Kimia Bubuk Ceker Ayam}

Kandungan komponen kimiawi sampel ceker ayam dalam bentuk bubuk disajikan pada Tabel 1. 
Tabel 1. Komposisi Kimia Bubuk Ceker Ayam

\begin{tabular}{cc}
\hline Parameter & Nilai \\
\hline Protein (\%) & $42,68 \pm 2,61$ \\
\hline Lemak (\%) & $25,50 \pm 1,19$ \\
\hline Air (\%) & $3,90 \pm 0,04$ \\
\hline Abu (\%) & $11,29 \pm 1,02$ \\
\hline Karbohidrat (\%) & $16,63 \pm 1,38$ \\
\hline
\end{tabular}

Identifikasi kadar protein ceker ayam sangat penting untuk tahapan selanjutnya yaitu sebagai data awal dalam mengetahui kandungan protein terlarut dan ekstrak peptida yang berfungsi sebagai antioksidan.

Berdasarkan Tabel 1 diketahui bahwa nilai kadar protein tertinggi dalam komposisi kimiawi bubuk ceker ayam sebesar $42,68 \%$, diikuti dengan kandungan lemak, karbohidrat dan abu. Hal ini menunjukkan bahwa kandungan protein ceker ayam broiler tidak berkurang akibat proses pengeringan dan penghalusan sampel. Kadar protein tersebut juga sebanding dengan hasil penelitian Widyaningsih et al. (2015) dan Dhyantari et al. (2015) dengan kisaran nilai kadar protein sebesar 42 - 47\%. Berdasarkan tabel 1 juga diketahui bahwa nilai komponen non protein seperti lemak, karbohidrat dan abu masih cukup tinggi. hal ini akan mempengaruhi proses ekstraksi protein dalam ceker ayam tersebut. Ikatan peptidoglican antara protein dan karbohidrat dalam ceker ayam merupakan pertimbangan khusus dalam menentukan jenis pelarut beserta $\mathrm{pH}$ yang optimum dalam ekstraksi protein terlarut dan peptida aktif (Liu et al., 2001). Kandungan lemak sebesar $25,5 \%$ menunjukkan bahwa ayam broiler menyimpan energi dalam bentuk jaringan adiphose hingga ke organ kaki yaitu dibagian ceker ayam. Saat proses ekstraksi protein, keberadaan lemak ini juga harus bisa dihilangkan secara maksimal.
Selain karbohidrat dan lemak, kandungan Abu atau mineral dalam bubuk ceker ayam juga cukup tinggi sebesar 11,29\%. Mineral merupakan salah satu komponen penting dalam ceker ayam. Mineral berinteraksi dengan protein membentuk matriks dalam membangun tulang ceker ayam. Katti et al. (2008) menyebutkan bahwa mineral mempengaruhi pola pergerakan protein melalui simulasi collagenhydroxyapatite dalam tulang. Sehingga keberadaan mineral harus bisa dipisahkan secara maksimal dalam proses ekstraksi protein ceker ayam.. Kadar air bubuk ceker ayam tercapai cukup rendah sebesar 3,90\% menunjukkan optimalnya proses pengeringan yang dilakukan. Hal ini bertujuan agar sampel tetap terjaga kualitas nya saat digunakan dalam jangka waktu yang cukup lama. Hettiarachchy dan Navam (2012) menjelaskan bahwa adanya air yang rendah dalam suatu bahan pangan akan menyebabkan struktur protein lebih tertutup sehingga potensi terdenaturasi dan hilangnya peptida bioaktif akan semakin kecil. Struktur tertutup yang dimaksud adalah terbentuknya ikatan peptida yang satu dengan yang lain sehingga menyebabkan potensi rantai samping hidrofobik lebih sedikit.

\section{Mikrostruktur Peptida Bioaktif Ceker Ayam}

Perlakuan konsentrasi enzim papain dan lama pemeraman pada peptida bioaktif ceker ayam menghasilkan mikrostruktur seperti pada Gambar 1 berikut ini. 

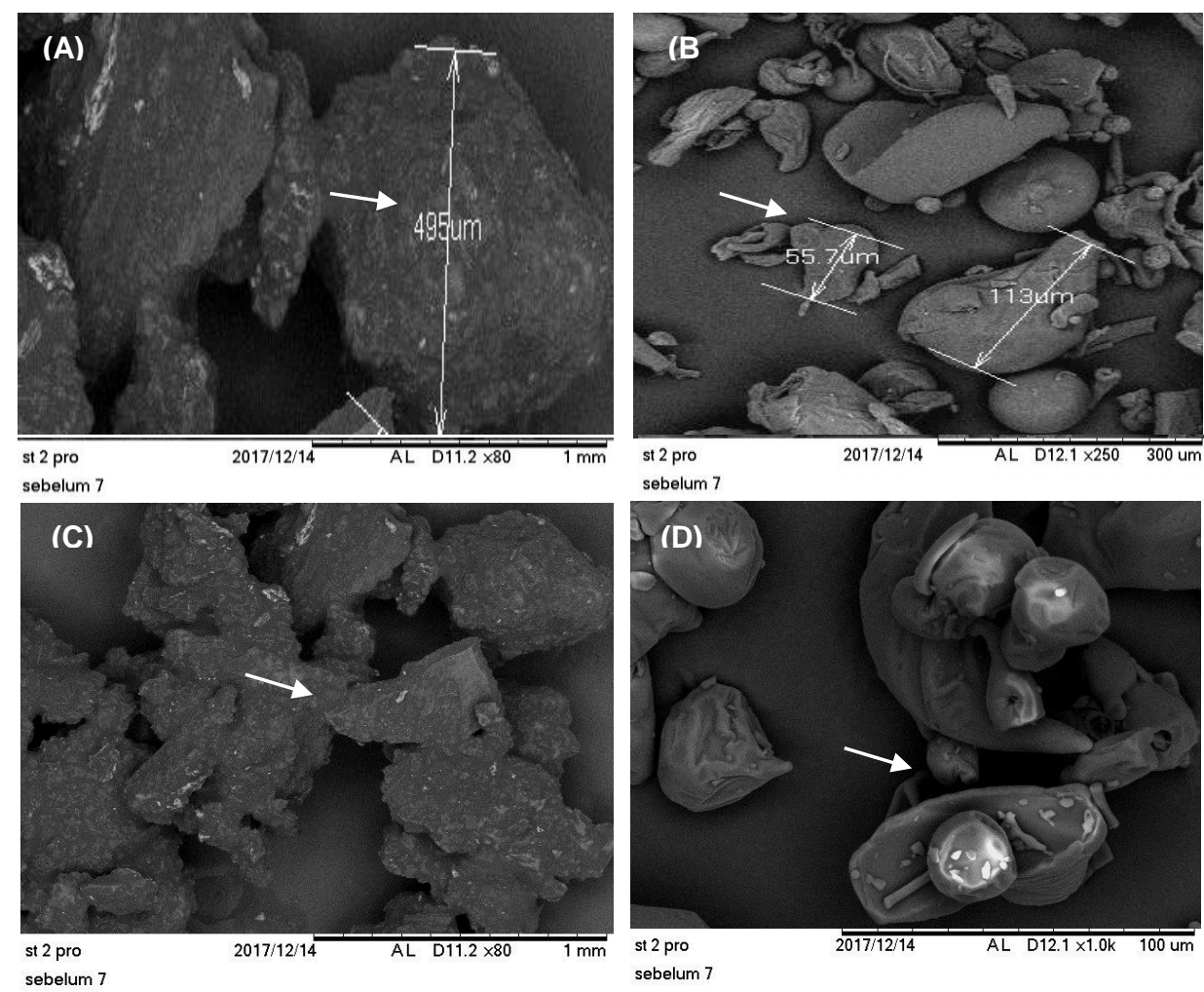

Gambar 1. Scanning Electron Microscopgraph Peptida Bioaktif Ceker Ayam pada perlakuan Konsentrasi Papain dan Lama Pemeraman yang berbeda. A: ekstrak protein ceker ayam yang belum mendapat perlakuan enzim papain; B: enzim papain 3\% dengan lama pemeraman 36 jam; C: struktur ekstrak protein ceker ayam yang belum diperlakukan enzim papain; D: struktur peptida ceker ayam yang diperoleh dari perlakuan konsentrasi enzim papain 3\% dengan lama pemeraman 36 jam

Secara umum pengaruh penggunaan enzim papain mampu merubah mikrostruktur peptida di dalam ceker ayam. Gambar 1 (A) merupakan ekstrak protein ceker ayam yang belum mendapat perlakuan enzim papain, ukuran nya sebesar $495 \mu \mathrm{m}$. Gambar 1 (B) menunjukkan terjadinya perubahan ukuran protein ceker ayam menjadi $55,7 \mu \mathrm{m}-113 \mu \mathrm{m}$ akibat perlakuan konsentrasi enzim papain 3\% dengan lama pemeraman 36 jam. Hal ini mengkonfirmasi variabel sebelumnya yang menyebutkan bahwa salah satu penyebab peningkatan aktifitas antioksidan sampel terhidrolisis enzim papain adalah akibat perubahan ukuran dan berat protein menjadi lebih kecil. Wang et al. (2017) menyatakan bahwa enzim papain mempunyai kemampuan proteolitik terhadap struktur dan ukuran protein yang besar dan tidak terlarut menjadi peptida yang berukuran lebih kecil dan terlarut. Efek perubahan mikrostruktur dalam protein kolagen maupun non kolagen dapat di gambarkan dengan SEM (Marelli and Simons, 2014).

Gambar 1 (C) merupakan struktur ekstrak protein ceker ayam yang belum diperlakukan enzim papain, sedangkan Gambar 1 (D) merupakan struktur peptida ceker ayam yang diperoleh dari perlakuan konsentrasi enzim papain 3\% dengan lama pemeraman 36 jam. Kedua gambar tersebut memperlihatkan perbedaan struktur yang sangat nyata. Penggunaan enzim papain mampu merubah struktur protein ceker ayam yang terlihat sangat padat dan kompak menjadi terpisah dan berbentuk bulat-elips. Hal ini disebabkan proses hidrolisis papain dapat memutus ikatan-ikatan dalam protein jaringan ikat ceker ayam serta menjadikan perubahan struktur primer polipeptida secara permanen. Damez dan Clerjon (2008) menjelaskan bahwa struktur jaringan ikat hewan yang terdiri dari tropokolagen dan polipeptida dengan struktur 
triple- $\alpha$-heliks secara fisik membentuk jaringan yang keras dan padat serta sulit larut dalam air. Enzim papain merupakan jenis eksoenzim yang mempunyai gugus sulfhidril mampu berfungsi sebagai proteolitik struktur triple- $\alpha$-heliks menjadi peptida sederhana secara irreversible yang menjadikan protein dapat larut dalam air (Han et al., 2016). Peptida yang lebih sederhana dapat berpotensi mengerahkan fungsi antioksidan secara baik (Chandrasekaran et al., 2016).

\section{Konsentrasi Protein Terlarut}

Penelitian tahap selanjutnya adalah hidrolisis protein ceker ayam dengan enzim papain yang hasilnya disajikan pada Tabel 2 . Berdasarkan analisis sidik ragam diketahui bahwa baik pada sampel larutan yang diambil di bagian atas (A) maupun bagian bawah (B) terdapat perbedaan pengaruh yang nyata
$(\mathrm{P}<0,05)$ faktor konsentrasi papain dan faktor lama pemeraman secara parsial terhadap konsentrasi protein terlarut.

Demikian pula dengan interaksi faktor konsentrasi papain dengan faktor lama pemeraman juga memberikan pengaruh yang nyata $(\mathrm{P}<0,05)$ terhadap konsenstrasi protein terlarut. Hal ini membuktikan bahwa enzim papain mampu menghidrolisis protein ceker ayam untuk menghasilkan protein terlarut yang lebih banyak. Lafarga, et al. (2016) menyatakan bahwa penggunaan enzim papain dengan aktifitas > $3 \mathrm{U} / \mathrm{mg}$ dan konsentrasi serta lama pemeraman yang cukup akan mampu memutus ikatan hidrogen maupun kovalen suatu protein yang sulit terlarut. Ditambahkan oleh Kezwoń et al. (2016) bahwa hidrolisis tidak hanya bergantung pada konsentrasi enzim, tetapi juga sangat dipengaruhi oleh lama inkubasi protein dengan enzim tersebut.

Tabel 2. Rerata konsentrasi protein terlarut

\begin{tabular}{|c|c|c|c|c|}
\hline \multirow{2}{*}{$\begin{array}{c}\text { Konsentrasi Papain } \\
(\%)\end{array}$} & \multicolumn{3}{|c|}{ Waktu Pemeraman (Jam) } & \multirow[t]{2}{*}{ Rataan $\pm \mathrm{SD}(\mathrm{mg} / \mathrm{ml})$} \\
\hline & 24 & 36 & 48 & \\
\hline $0 \%$ (A) & $1,38 \pm 0,06$ & $1,39 \pm 0,05$ & $1,39 \pm 0,04$ & $1,38 \pm 0,00^{\mathrm{a}}$ \\
\hline $0 \%(\mathrm{~B})$ & $0,76 \pm 0,00$ & $0,76 \pm 0,01$ & $0,77 \pm 0,02$ & $0,76 \pm 0,01^{\mathrm{C}}$ \\
\hline $1 \%(\mathrm{~A})$ & $1,39 \pm 0,04$ & $1,50 \pm 0,08$ & $1,31 \pm 0,03$ & $1,40 \pm 0,10^{\mathrm{a}}$ \\
\hline $1 \%(\mathrm{~B})$ & $0,76 \pm 0,01$ & $0,75 \pm 0,00$ & $0,77 \pm 0,01$ & $0,76 \pm 0,01^{\mathrm{BC}}$ \\
\hline $2 \%(\mathrm{~A})$ & $1,46 \pm 0,03$ & $1,62 \pm 0,04$ & $1,44 \pm 0,06$ & $1,51 \pm 0,10^{\mathrm{b}}$ \\
\hline $2 \%(\mathrm{~B})$ & $0,74 \pm 0,00$ & $0,74 \pm 0,00$ & $0,75 \pm 0,01$ & $0,74 \pm 0,01^{\mathrm{A}}$ \\
\hline $3 \%(\mathrm{~A})$ & $1,39 \pm 0,01$ & $1,47 \pm 0,10$ & $1,36 \pm 0,04$ & $1,40 \pm 0,06^{\mathrm{a}}$ \\
\hline $3 \%(\mathrm{~B})$ & $0,76 \pm 0,01$ & $0,76 \pm 0,01$ & $0,76 \pm 0,01$ & $0,76 \pm 0,00^{\mathrm{B}}$ \\
\hline \multirow[t]{2}{*}{ Rataan \pm SD $(\mathrm{mg} / \mathrm{ml})$} & $1,41 \pm, 04^{\mathrm{a}}$ & $1,49 \pm 0,10^{\mathrm{b}}$ & $1,37 \pm 0,05^{\mathrm{a}}$ & \\
\hline & $0,75 \pm 0,01^{\mathrm{A}}$ & $0,75 \pm 0,01^{\mathrm{A}}$ & $0,76 \pm 0,01^{\mathrm{B}}$ & \\
\hline
\end{tabular}

Keterangan: ${ }^{a, b}$ (A, B) Superskrip yang berbeda dan pada baris yang sama menunjukkan perbedaan yang nyata $(\mathrm{P}<0,05)$, Superskrip yang berbeda $(a, b)$ dan $(A, B, C)$ pada kolom yang sama menunjukkan perbedaan yang nyata $(P<0,05)$, (A) Larutan Fraksi Atas, (B) Larutan Fraksi Bawah

Tabel 2 menunjukkan bahwa nilai konsentrasi protein terlarut yang diperoleh dari sampel larutan bagian atas (A) lebih tinggi dari pada sampel larutan bagian bawah (B) dengan kisaran masing-masing $1,31-1,62 \mathrm{mg} / \mathrm{ml}$ dibanding $0,74-0,76 \mathrm{mg} / \mathrm{ml}$. Nilai tersebut sesuai dengan prinsip umum sentrifugasi bahwa protein yang mempunyau ukuran dan berat partikel lebih rendah dan seragam akan berada di atas begitu juga sebaliknya. Hal ini berarti konsentrasi protein optimal diperoleh di larutan bagian atas. Hal ini sesuai dengan pendapat Griffith (2010) dan Mäkeläinen dan Heikkinen (2016) bahwa tingkat sedimentasi sangat 
dipengaruhi oleh viskositas, densitas, kecepatan sentrifugasi dan ukuran partikel di dalam suatu larutan.

Pola pengaruh konsentrasi dan lama pemeraman enzim papain terhadap protein terlarut yang diperoleh dapat dilihat pada Gambar 2.

Secara umum Gambar 2 memperlihatkan bahwa kenaikan konsentrasi protein terlarut sebanding dengan peningkatan konsentrasi dan lama pemeraman enzim papain. Namun terlihat pada tingkat tertentu terjadi penurunan. Gambar 2 (A) memperlihatkan bahwa konsentrasi protein terlarut tertinggi $(1,51 \mathrm{mg} / \mathrm{ml})$ diperoleh dari penambahan $2 \%$ konsentrasi enzim papain namun menurun pada konsentrasi 3\%. Hal ini menunjukkan bahwa optimasi hidrolisis protein dipengaruhi oleh adanya keseimbangan antara keberadaan enzim dan keberadaan substrat. Substrat yang dimaksud adalah protein ceker ayam. Pada konsentrasi 3\%, keberadaan enzim terlalu tinggi dibandingkan dengan proteinnya sehingga hidrolisis tidak maksimal dan terjadi penurunan konsentrasi protein terlarut. Ojha et al. (2016) menjelaskan bahwa kemampuan proteolitic enzim protease akan menurun saat rasio antara enzim dan substrat tidak seimbang. Ditambahkan oleh Selvakumar et al. (2012) bahwa keberadaan enzim papain pada konsentrasi yang tepat mampu memutus ikatan polipeptida khususnya lokasi asam amino ProHyP-Pro sehingga didapat recovery kolagen terlarut dan peptida bioaktif yang tinggi dan mempunyai aktifitas antioksidan.

(A)

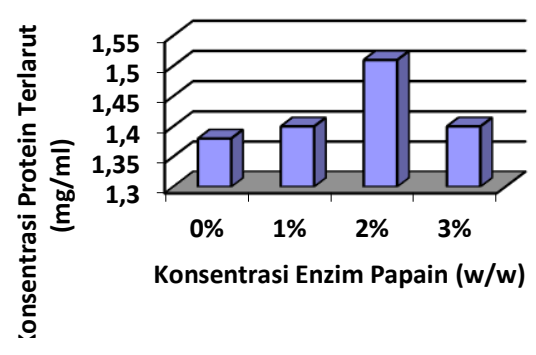

(B)

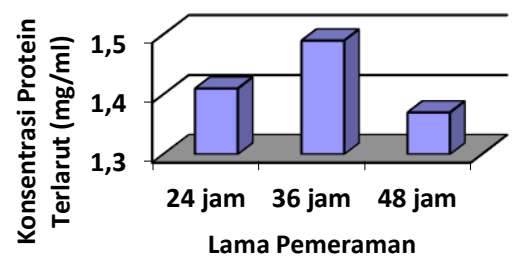

$\square$ Konsentrasi Protein

Terlarut (mg/ml)

Gambar 2. Grafik Pengaruh Konsentrasi (A) dan Lama Pemeraman (B) Enzim Papain terhadap Konsentrasi Protein Terlarut

Berdasarkan gambar 2 (B) juga diketahui bahwa peningkatan konsentrasi protein terlarut sebanding dengan lama pemeraman, namun terjadi penurunan pada tingkat tertentu. Konsentrasi protein terlarut yang tertinggi $(1,49$ $\mathrm{mg} / \mathrm{ml}$ ) diperoleh dari perlakuan lama pemeraman 36 jam dan menurun lagi pada lama pemeraman 48 jam. Hal ini disebabkan perbedaan aktifitas proteolitic enzim papain pada selang waktu tersebut. Beberapa faktor yang mempengaruhi aktifitas enzim protease adalah $\mathrm{pH}$, suhu, konsentrasi dan lama inkubasi atau pemeraman (Zarei et al., 2014) yang oleh Mcbroom dan Oliver-hoyo (2007) dijelaskan bahwa terjadi pola kurva terbalik hubungan antara lama inkubasi dengan aktifitas enzim dalam menghidrolisis protein. Pola tersebut disebabkan adanya perilaku kinetik enzim terhadap substratnya sehingga pada waktu tertentu akan terjadi aktifitas yang antiklimaks. 


\section{Aktifitas Antioksidan Peptida aktif Ceker Ayam}

Hasil analisis sidik ragam menunjukkan bahwa pada sampel larutan fraksi atas (A) terdapat perbedaan pengaruh yang nyata $(\mathrm{P}<0,05)$ konsentrasi enzim papain dan lama pemeraman yang berbeda terhadap aktifitas antioksidan peptida ceker ayam. Namun demikian, hal tersebut tidak terjadi pada sampel larutan fraksi bawah (B). Nilai aktifitas antioksidan sampel larutan bagian atas berada di kisaran 33,51\% - 55,10 \% lebih tinggi dari nilai aktifitas antioksidan yang diperoleh pada sampel larutan bagian bawah yang berkisar $6,60 \%-6,90 \%$. Nilai tersebut sebanding dengan konsentrasi protein terlarut yang didapat, dimana pada larutan bagian atas konsentrasi protein yang didapat lebih tinggi dari pada larutan bagian bawah. Hal ini sesuai dengan pendapat Bamdad et al. (2011) bahwa hidrolisis enzim mampu meningkatkan nilai protein terlarut yang sebanding dengan peningkatan aktivitas antioksidan. Damgaard et al. (2015) juga menyatakan perubahan nilai aktifitas antioksidan pada by product peternakan dapat terjadi akibat proses hidrolisis enzimatis yang menghasilkan respon asam amino dan distribusi ukuran peptida yang berbeda.

Rerata aktifitas antioksidan hasil perlakuan variasi konsentrasi enzim papain dan lama pemeraman disajikan pada Tabel 3.

Tabel 3. Rerata pengaruh konsentrasi papain dan lama waktu pemeraman terhadap Aktifitas Antioksidan

\begin{tabular}{ccccc} 
Sampel & $\begin{array}{c}\text { Konsentrasi } \\
\text { Protein }(\mathbf{A}) \\
(\mathbf{m g} / \mathbf{m l})\end{array}$ & $\begin{array}{c}\text { Aktifitas } \\
\text { Antioksidan } \\
(\mathbf{A}) \mathbf{( \% )}\end{array}$ & $\begin{array}{c}\text { Konsentrasi Protein } \\
(\mathbf{B}) \mathbf{( m g / m l})\end{array}$ & $\begin{array}{c}\text { Aktifitas } \\
\text { Antioksidan } \\
(\mathbf{B})(\boldsymbol{\%})\end{array}$ \\
\hline Papain 0\%, 24 jam & $1,38 \pm 0,06$ & $44,38 \pm 1,88$ & $0,76 \pm 0,00$ & $6,84 \pm 0,83$ \\
\hline Papain 1\%, 24 jam & $1,39 \pm 0,04$ & $49,30 \pm 1,03$ & $0,76 \pm 0,01$ & $6,89 \pm 0,99$ \\
\hline Papain 2\%, 24 jam & $1,46 \pm 0,03$ & $50,30 \pm 4,07$ & $0,74 \pm 0,00$ & $6,75 \pm 0,75$ \\
\hline Papain 3\%, 24 jam & $1,39 \pm 0,01$ & $49,53 \pm 2,73$ & $0,76 \pm 0,01$ & $6,94 \pm 0,92$ \\
\hline Papain 0\%, 36 jam & $1,39 \pm 0,05$ & $46,03 \pm 3,90$ & $0,76 \pm 0,01$ & $6,69 \pm, 99$ \\
\hline Papain 1\%, 36 jam & $1,50 \pm 0,08$ & $51,94 \pm 2,79$ & $0,75 \pm 0,00$ & $6,97 \pm 0,74$ \\
\hline Papain 2\%, 36 jam & $1,62 \pm 0,04$ & $49,88 \pm 3,09$ & $0,74 \pm 0,00$ & $6,60 \pm 0,83$ \\
\hline Papain 3\%, 36 jam & $1,47 \pm 0,10$ & $55,10 \pm 2,24$ b & $0,76 \pm 0,01$ & $6,79 \pm 0,99$ \\
\hline Papain 0\%, 48 jam & $1,39 \pm 0,04$ & $33,51 \pm 3,12$ & $0,77 \pm 0,02$ & $6,71 \pm 0,75$ \\
\hline Papain 1\%, 48 jam & $1,31 \pm 0,03$ & $44,32 \pm 6,84$ & $0,77 \pm 0,01$ & $6,99 \pm 0,83$ \\
\hline Papain 2\%, 48 jam & $1,44 \pm 0,06$ & $49,86 \pm 3,51$ & $0,75 \pm 0,01$ & $6,62 \pm 0,99$ \\
\hline Papain 3\%, 48 jam & $1,36 \pm 0,04$ & $41,65 \pm 5,46$ & $0,76 \pm 0,01$ & $6,80 \pm 0,75$ \\
\hline
\end{tabular}

Keterangan: ${ }^{\mathrm{b}}$ Superskrip menunjukkan nilai tertinggi dengan signifikansi yang nyata $(\mathrm{P}<0,05)$

(A) : Larutan fraksi atas, (B) : Larutan fraksi bawah

Tabel 3 menunjukkan bahwa aktifitas antioksidan tertinggi sebesar $55,10 \%$ diperoleh dari perlakuan konsentrasi enzim papain 3\% dengan lama pemeraman 36 jam. Hasil tersebut sedikit berbeda dengan variabel sebelumnya yaitu konsentrasi protein terlarut tertinggi diperoleh dari perlakuan konsenstrasi enzim papain $2 \%$ dengan lama pemeraman 36 jam. Hal ini mengindikasikan bahwa tidak semua komponen protein terlarut hasil hidrolisis enzimatik tersebut merupakan peptida yang berfungsi sebagai antioksidan. Pada perlakuan papain 3\% mampu menghasilkan komposisi asam amino hidrofobik yang lebih banyak dari pada yang lain serta distribusi ukuran berat molekul yang sesuai. Hal ini sesuai pendapat Arcan dan Yemeniciog (2010) bahwa besarnya nilai aktifitas antioksidan bergantung pada 
komposisi asam amino hidrofobik dan ditambahkan oleh Alpay dan Aktas (2015) bahwa distribusi ukuran berat molekul peptida 3 $\mathrm{KDa}-20 \mathrm{KDa}$ hasil hidrolisis enzim juga berpotensi menghasilkan aktifitas antioksidan

\section{Aktifitas Antioksidan (\%) Larutan Fraksi Bawah}

yang tinggi. Pola aktifitas antioksidan hasil perlakuan konsentrasi enzim papain dan lama pemeraman yang berbeda ditunjukkan dengan grafik pada Gambar 3.

\section{Aktifitas Antioksidan (\%) Larutan Fraksi Atas}

Gambar 3. Grafik Pengaruh Papain terhadap \% Aktifitas Antioksidan Larutan Fraksi Atas (A) dan Fraksi Bawah (B)

Gambar 3 memperlihatkan bahwa pola perlakuan variasi konsentrasi enzim papain dan lama pemeraman terhadap sampel yang diambil dari larutan fraksi atas (A) ada kecenderungan meningkat dibanding fraksi bawah (B) yang terlihat tidak beraturan, walaupun pada tingkat lama pemeraman tertentu terjadi penurunan kembali. Perlakuan konsentrasi enzim papain sebanding dengan peningkatan aktifitas antioksidan yang diperoleh, semakin tinggi konsentrasi enzim papain maka semakin tinggi pula aktifitas antioksidan. Namun demikian, hal tersebut tidak terjadi pada perlakuan lama pemeraman. Peningkatan terjadi pada lama pemeraman 24 jam ke 36 jam, namun pada lama pemeraman 48 jam terjadi penurunan nilai aktifitas antioksidan. Hal ini serupa dengan variabel sebelumnya bahwa terjadi penurunan aktifitas enzim papain pada masa inkubasi yang terlalu lama, sehingga proses hidrolisis tidak optimal. Zarei et al. (2014) menjelaskan bahwa aktifitas enzim papain sangat dibatasi oleh energi kinetik yang dipengaruhi oleh lamanya bekerja pada substrat sehingga terjadi ketidakseimbangan enzim-substrat di dalamnya.
Pada Gambar 3 (A) diketahui bahwa perlakuan hidrolisis enzim papain mampu meningkatkan aktifitas antioksidan sebesar 21,59\%. Nilai tersebut dihitung dari aktifitas antioksidan tertinggi hasil perlakuan papain 3\% selama 36 jam $(55,10 \%)$ dikurangi nilai aktifitas antioksidan terendah hasil perlakuan papain $0 \%$ selama 48 jam $(33,51 \%)$. Hasil tersebut menunjukkan bahwa enzim papain sangat efektif dalam menghidrolisis polipeptida menjadi peptida-peptida aktif yang mempunyai fungsi antioksidan.

Kusumadjaja dan Dewi (2005) menyatakan bahwa enzim papain mempunyai gugus fungsional sulfhidril yang mampu memutus rantai ikatan peptida pada lokasi asam amino lisin dan glisin. Siow dan Gan (2013) juga melaporkan bahwa asam amino lisin dan glisin mempunyai gugus amina yang bersifat hidrofobik, sehingga mudah mereduksi radikal bebas DPPH dalam aktifitas antioksidannya. Hal ini didukung oleh hasil data variabel selanjutnya tentang profil dan komposisi asam amino yang diperoleh. 


\section{KESIMPULAN}

Kesimpulan penelitian ini adalah ceker ayam menghasilkan komponen peptida bioaktif yang menghasilkan aktivitas antioksidan yang tinggi yang dioptimalkan melalui hidrolisis enzim papain sehingga meningkatkan nilai fungsionalnya.

\section{UCAPAN TERIMA KASIH}

Penulis mengucapkan terima kasih yang sebesar-besarnya kepada Kemenristek DIKTI atas diberikannya beasiswa program Doktor di Universitas Brawijaya, kepada Rektor Universitas Islam Lamongan dan Kopertis 7 Jawa Timur atas rekomendasi Tugas Belajar yang diberikan.

\section{DAFTAR PUSTAKA}

Alpay, P., \& Aktas, D. (2015). Journal of Molecular Catalysis B : Enzymatic Usage of immobilized papain for enzymatic hydrolysis of proteins. $J$ Molecular Catalysisi B; Enzimatic, 111, 56-63. https://doi.org/10.1016/j.molcatb.2014.11.001

Arcan, I., \& Yemeniciog, A. (2010). Effects of controlled pepsin hydrolysis on antioxidant potential \& fractional changes of chickpea proteins. J Food Research International, 43, 140-147. https://doi.org/10.1016/j.foodres.2009.09.012

Bamdad, F., Wu, J., \& Chen, L. (2011). Effects of enzymatic hydrolysis on molecular structure \& antioxidant activity of barley hordein. Journal of Cereal Science, 54(1), 20-28. https://doi.org/10.1016/j.jcs.2011.01.006

Chandrasekaran Prabaharan, M. T. (2016). Production of antioxidant peptides from ferula asafoetida root protein. Int $J$ Molecular Biology, 1(1), 1-7. https://doi.org/10.15406/ijmboa.2016.01.00003
Damez, J.-L., \& Clerjon, S. (2008). Meat quality assessment using biophysical methods related to meat structure. Meat Science, $\quad 80(1), \quad 132-149$. https://doi.org/10.1016/j.meatsci.2008.05.039

Damgaard, T., Lametsch, R., \& Otte, J. (2015). Antioxidant capacity of hydrolyzed animal by-products and relation to amino acid composition and peptide size distribution. $J$ Food Sci Technol, 52(October), 65116519.https://doi.org/10.1007/s13197-0151745-z

Dhyantari, O., Milala, C. T., \& Widyaningsih, T. D. (2015). Tikus wistar jantan yang diinduksi karagenan The Use Chicken Foot Extraction as the Source of Glucosamine as Anti-Accute Inflamation Agent by In Vivo, 3(3), 888-895.

Escudero, E., Mora, L., Fraser, P. D., Aristoy, M.-C., \& Toldrá, F. (2013). Identification of novel antioxidant peptides generated in Spanish dry-cured ham. Food Chemistry, 138(2-3), 1282-8. https://doi.org/10.1016/j.foodchem.2012.10.133

Griffith, O. (2010). Practical Techniques for Centrifugal Seperations. Principles \& Techniques of Biochemistry and Molecular Biology, 1-27.

Han, Z., Zhang, W., Luo, W., \& Li, J. (2016). Novel Antioxidant Peptides Derived from Enzymatic Hydrolysates of Macadamia Protein. J Biosciences \& Medicines, 4(February),6-14. https://doi.org/http://dx.doi.org/10.4236/jbm.2016.42002

Hettiarachchy, Navam, S. (2012). Bioactive Food Proteins and Peptides: Applications in Human Health. (A. Kenji, Sato, Marshall, M.R., Kannan, Ed.) (1st ed.). New York: CRC Press Taylor \& Francis Group. 
Katti, D. R., Ghosh, P., \& Katti, K. S. (2008). Mineral and protein-bound water \& latching action control mechanical behavior at protein-mineral interfaces in biological nanocomposites. Journal of Nanomaterials, https://doi.org/10.1155/2008/582973

Kezwoń, A., Chromińska, I., Frączyk, T., \& Wojciechowski, K. (2016). Effect of enzymatic hydrolysis on surface activity \& surface rheology of type I collagen. Colloids and Surfaces. B, Biointerfaces, 137,60-9.

https://doi.org/10.1016/j.colsurfb.2015.05.017

Kusumadjaja, A. P., \& Dewi, R. P. (2005). Determination of optimum condition of papain enzyme from papaya var java ( carica papaya ) penentuan kondisi optimum enzim papain dari pepaya burung varietas jawa. Indo J. Chem, 5(2), 147-151.

Lafarga, T., Aluko, E.R., Rai, D.K., O'Connor, P., \& Hayes, M. (2016). Identification of bioactive peptides from a papain hydrolysate of bovine serum albumin \& assessment of an . J. Food Research International, 81(January), 9199.https://doi.org/10.1016/j.foodres.2016.01.007

Lin, Y. J., Le, G. W., Wang, J. Y., Li, Y. X., Shi, Y. H., \& Sun, J. (2010). Antioxidative peptides derived from enzyme hydrolysis of bone collagen after microwave assisted acid pre-treatment and nitrogen protection. International Journal of Molecular Sciences, 11(11), 4297-4308. https://doi.org/10.3390/ijms11114297

Liu, D. C., Lin, Y. K., \& Chen, M. T. (2001). Optimum Condition of Extracting Collagen from Chicken Feet \& its Characetristics. Asian-Australasian Journal of Animal Sciences.https://doi.org/10.5713/ajas.2001.1638
Mäkeläinen, I., \& Heikkinen, J. (2016). Centrifugation Downstream processing assignment. Aalto University The University of the Chemical Technology.

Marelli, C. A., \& Simons, E. L. R. (2014). Microstructure \& cross-sectional shape of limb bones in great horned owls \& redtailed hawks : how do these features relate to differences in flight \& hunting behavior? J Pone, 9(8). https://doi.org/10.1371/journal.pone.0106094

Mcbroom, R., \& Oliver-hoyo, M. T. (2007). Food Enzyme (2nd ed.). University of Georgia: Aspen Publishers.

Molyneux, P. (2004). The use of the stable free radical diphenylpicrylhydrazyl (dpph) for estimating antioxidant activity. Songklanakarin J. Sci. Tech., 26(2), 211-219.

Ojha, K. S., Alvarez, C., Kumar, P., O’Donnell, C. P., \& Tiwari, B. K. (2016). Effect of enzymatic hydrolysis on the production of free amino acids from boarfish (Capros aper) using second order polynomial regression models. LWT - Food Science and Technology, 68, 470-476. https://doi.org/10.1016/j.lwt.2015.11.040

Rahmawati, N., Kimia, J., Matematika, F., Ilmu, D. A. N., Alam, P., \& Jember, U. (2013). Kandungan Protein Terlarut Daging Ikan Patin ( Pangasius Djambal ) Akibat Variasi Pakan Kandungan Protein Terlarut Daging Ikan Patin ( Pangasius djambal ) akibat variasi pakan.

Selvakumar, P., Ling, T. C., Covington, A. D., \& Lyddiatt, A. (2012). Enzymatic hydrolysis of bovine hide and recovery of collagen hydrolysate in aqueous two-phase systems. Separation \& Purification Technology, 89, 282-287. https://doi.org/10.1016/j.seppur.2012.01.046 
Siow, H.-L., \& Gan, C.-Y. (2013). Extraction of antioxidative \& antihypertensive bioactive peptides from Parkia speciosa seeds. Food Chemistry, 141(4), 3435-3442. https://doi.org/10.1016/j.foodchem.2013.06.030

Subali, B. (2010). Analisis statistika menggunakan program SPSS aplikasinya dalam rancangan percobaan. jurusan pendidikan biologi, Fakultas MIPA, Universitas Negeri Yogyakarta. Yogyakarta.

Susanto, E., Rosyidi, D., Radiati, L. E., \& Subandi. (2018). Optimization of chicken feet protein degradation with variation of ph and temperature on characteristics \& antioxidant activity. Submit The Journal of Poultry Science, 1-19.

Wang, X., Yu, H., Xing, R., Chen, X., Liu, S., \& Li, P. (2017). Optimization of the Extraction \& Stability of Antioxidative Peptides from Mackerel ( Pneumatophorus japonicus ) Protein. J BioMed Research International, 2017(2), 1-14. https://doi.org/https:/doi.org/10.1155/2017/6837285
Widyaningsih, T. D., Handayani, D., Wijayanti, N., Dita, S., \& Milala, C. (2015). Ekstraksi glukosamin dari ceker ayam, (September), 2-3.

Xing, L.-J., Hu, Y.-Y., Hu, H.-Y., Ge, Q.-F., Zhou, G.-H., \& Zhang, W.-G. (2016). Purification \& identification of antioxidative peptides from dry-cured Xuanwei ham. Food Chemistry, 194, 9518.

https://doi.org/10.1016/j.foodchem.2015.08.101

Zarei, M., Ebrahimpour, A., Abdul-hamid, A., Anwar, F., Abu, F., Philip, R., \& Saari, N. (2014). Identi fi cation \& characterization of papain-generated antioxidant peptides from palm kernel cake proteins. J Food Research International, 62, 726-734. https://doi.org/10.1016/j.foodres.2014.04.041 